ably best be served by friendship with Ibn Saud. Granting this, the general rule denying the materiality of such an argument seems appropriate. ${ }^{67}$ Courts are not competent to investigate the merits of particular proposals. Courts appeal to public policy to deny recovery where officials might be moved by overwhelming personal influence or personal solicitation to act in a way in which, upon independent judgment, they would not act. When a party seeks compensation for his services, it is clear that public benefit was not his only motive. Any public benefit is coincidental as far as he is concerned. The argument which denies recovery where no public benefit appears remains just as sound where it does.

This discussion has encompassed an analysis of factors which might be considered by a court in determining whether a party ought to be relieved from promissory liability on grounds of public policy under fact situations suggested by the principal case. Needless to say, there is no absolute answer to be given as to how a court should act in these circumstances. Certain general observations can be made. Courts ought to be articulate as to their reasons for denying recovery. Where the evidence indicates a possibility of reasonable differences in conclusions about the type of acts contemplated or done under the agreement, the court ought to submit the issue to the jury. Courts ought to recognize that they are carrying on an evaluative process, and they should use statutes and administrative regulations, directly or by analogy, where these sources indicate criteria of public policy.

\title{
TAXATION OF FAMILY PARTNERSHIP INCOME- THE TOWER DOCTRINE REINTERPRETED
}

The problem of correlating tax incidence to various intra-family financial transactions has long been a stumbling block in federal income tax law. The family partnership involved in the recent case of Comm'r v. Culbertson ${ }^{\mathrm{x}}$ again brought this correlation problem before the Supreme Court. Except as to trusts, ${ }^{2}$ the Internal Revenue Code sheds little light on the problem, and the courts have been compelled to rely on the broad language of Section 22(a), ${ }^{3}$ defining gross income, as their only guide. In putting content into Section 22(a) the courts have evolved three basic principles applicable to these transactions.

67 See note 64 supra.

${ }^{x} 337$ U.S. 733 (I949).

${ }^{2}$ Int. Rev. Code $\$ \$ 166,167,26$ U.S.C.A. $\$ \$ 166,167$ (1945), assess the tax to the grantor when power to revest the corpus rests in him or in a person not having a substantial adverse interest to him, or where the income of the trust is applied to the benefit of the grantor. These provisions, while of help, did not solve all the problems of the family trust. See text at note II.

3 Int. Rev. Code \$ 22(a), 26 U.S.C.A. \& 22(a) (I948). The provision reads (in part): " "Gross income' includes gains, profits, and income derived from salaries, wages, or compensation for personal services ... of whatever kind and in whatever form paid, or from professions, vocations, trades, businesses, commerce, or sales, or dealings in property, whether real or personal growing out of the ownership or use of an interest in such property; also from interest, rent, dividends, securities, or the transaction of any business carried on for gain or profit, or gains or profits and income derived from any source whatever. ..."? 
(I) Income dexived from personal services has been taxed to the person performing the services, and it has long been held that such income cannot be given away so as to avoid the imposition of taxes upon the donor. The Supreme Court set forth this rule in the leading case of Lucas v. Earl, 4 holding that an agreement between husband and wife to split the income from the husband's law practice could not be recognized for income tax purposes.

(2) An assignment of only the income from property, as distinguished from a gift of property itself, has similarly been denied tax recognition. In Helvering $v$. Horst, 5 the Supreme Court held a gift of interest coupons from negotiable bonds insufficient to transfer tax incidence on the ground that the coupons were income rather than property. The determination of whether a gift is one of property or one of income is complicated by the stock legal principles which may be applicable to such tax-motivated gifts. ${ }^{6}$ Thus a vigorous dissent was voiced in the Horst case that the decision violated the legal concepts attached to negotiable bond certificates. And in the Supreme Court case of Blair v. Comm' ${ }^{7}$ an assignment of a portion of the income beneficiary's interest for the life of the donee was held to be a gift of "equitable" property for tax purposes. Yet in Barrison v. Schaffner ${ }^{8}$ that Court held that a gift of a specific sum for the particular year out of the beneficiary's income from the trust was an assignment of income and insufficient to transfer tax incidence to the donee.

(3) Although the courts have always affirmed the right of a taxpayer to transfer tax incidence on income from capital by a gift of income-producing property, tax incidence has not been transferred where the donor retains such control over the property that the gift results merely in a "paper" redistribution of the property. A family relationship between the donor and the donee, making it easier for the donor to retain such control, will frequently color the transaction so as to indicate that no redistribution took place. The Supreme Court confirmed this doctrine in Helvering $v$. Clifford, 9 holding that a shortterm trust agreement which had given the husband-trustee-settlor a large element of control over the corpus was insufficient to transfer tax incidence on the income to the wife-beneficiary.

The problem of determining what restrictions so fetter a gift as to render it only a "paper" redistribution has not proved an easy one. The tax effects to be given a trust, the most flexible gift device, have been partially set forth by legislation. ${ }^{\mathrm{x}}$ In addition, the Treasury has promulgated comprehensive and

428 I U.S. III (I930).

${ }^{5} 3$ II U. S. III2 (I940).

${ }^{6}$ The courts have often said that substance will control rather than the legal niceties. Doll $\mathrm{v}$. Comm'r, I49 F. 2d 239, 243 (C.C.A. 8th, I945). However, this philosophy was never extended to mean that the body of tax law could grow up independent of the legal relationships involved in a negotiable bond, a trust, a corporation, a partnership, or any other of the gift devices used by the taxpayer.

7300 U.S. 5 (1937).

${ }^{8} 3$ I2 U.S. 579 (I94I).
${ }^{9} 309$ U.S. 33 I (I940).

to Note 2 supra. 
specific regulations, based on the Clifford case and similar decisions, stating the limits of the controls which the settlor can retain without invalidating the trust for tax purposes. ${ }^{\text {II }}$ Yet regulations alone cannot solve the problem, as the continuing litigation indicates. ${ }^{12}$ While gifts of property through transfer of stock in a family corporation have likewise caused the courts difficulty, ${ }^{13}$ such gifts have generally been held sufficient to transfer tax incidence on distributions to the donee. The nature of corporate interests lends color to any gift of stock as an actual redistribution of property, for unlike a trust beneficiary, the rights of the donee against the corporation do not depend on the terms of the gift. In significant contrast, whatever rights the donor reserves must be in derogation of the normal incidents of stock ownership, so that the courts are given a clear standard by which to determine whether a redistribution of property has taken place. Nevertheless, if the corporation is closely held, the donor may not have to rely on the terms of the gift to exercise control over the property given, since such control can instead stem from his dominant position in the corporation. I $_{4}$ As a result, "paper" redistributions which were thrown out the front door by the Clifford doctrine when accomplished by trusts, may have reentered the side door in the guise of intra-family stock gifts in closely-held corporations.

In summary, the courts must guard against the rerouting of income derived from personal services; they must distinguish an assignment of income from a gift of property, and refuse to shift tax incidence where the transaction is in essence an assignment of income; they must determine whether a gift of property is so fettered with restrictions as to result in a mere "paper" redistribution, in which case the tax is to be imposed on the donor. The gift of an interest in a family partnership can involve any or all of these principles, and in the absence of specific legislation, such gifts have been a continuous source of difficulty for the courts. ${ }^{15}$

The partnership has been an appealing device for tax minimization. It is not recognized as a taxable entity, and the tax is imposed on each partner for

Ir Treas. Reg. III, $\S 29.22(a)-2 I$ (1946). For a full discussion of these provisions see Guterman, The New Clifford Regulations, I Tax L. Rev. 379 (I946).

${ }^{22}$ Schmidt v. Glen, r72 F. 2d 863 (C.A. 6th, r949); Farkas v. Comm'r, r7o F. 2d 201 (C.A. 5 th, 1948); W. H. Easley, 8 T.C. I53 (r947).

${ }^{23}$ Lawton v. Comm'r, I64 F. 2 d 380 (C.C.A. 6th, I948); Overton v. Comm'r, 162 F. $2 \mathrm{~d}$ I55 (C.C.A. $2 \mathrm{~d}$, 1947 ).

${ }^{4}$ In Joseph Cohen, 2 T.C.M. 602 (1943), the Tax Court found the gift of corporate stock void for tax purposes, since the petitioner had maintained control over the dividends and none of the donees had participated in any control or management of the corporation. In Sewell v. Comm'r, 15 I F. 2 d 765 (C.C.A. 5th, 1945), cert. den. 327 U.S. 783 (1945), the gift was held insufficient to transfer tax incidence, since the donors retained the same control over the stock after the gift as before. Compare Anderson v. Comm'r, r64 F. 2d 870 (C.C.A 7th, r947) cert. den. 334 U.S. 8Ig (I948).

${ }^{15}$ See Paul, Partnerships in Tax Avoidance, 13 Geo. Wash. L. Rev. I2I, I24 (I945). 
his share of the income. ${ }^{16}$ With the increase in tax rates in the late I930's and the imposition of an excess profits tax upon corporations in I940, more and more taxpayers saw in the partnership a means to lower the taxes on their business income. The intra-family transfer of a partnership interest furnished a particularly convenient opportunity for tax avoidance. The acceptance as a business norm of the "silent" partner, the partner who performs no services and takes no part in the conduct of the partnership, and the inherent restrictions upon alienability of the partnership interest make such a "gift" convenient for a donor who wants to retain control over the property "given." The Commissioner asserted that many such family partnerships were sham, and since he was forced to rely for precedent primarily on Lucas v. Earl and on the broad terms of Section 22(a) of the Code, it was inevitable that a flood of litigation should commence. ${ }^{17}$

In addition to disagreements within the Tax Court, the circuit courts did not agree on the controlling legal principles. At this stage of events, the Supreme Court in 1946 handed down its landmark decision in Comm'r v. Tower. ${ }^{18}$ Justice Black there declared:

There can be no question that a wife and a husband may, under certain circumstances, become partners for tax, as for other, purposes. If she either invests capital originating with her or substantially contributes to the control and management of the business, or otherwise performs vital services, or does all of these things, she may be a partner.... But when she does not share in the management and control of the business, contributes no vital additional service, and where the husband purports in some way to have given her a partnership interest, the Tax Court may properly take these circumstances into consideration in determining whether the partnership is real within the meaning of the federal revenue laws..$^{\text {I9 }}$

Utilizing these tests of original capital, vital services, and control and management of the business, the Tax Court proceeded to invalidate for tax purposes many of the partnerships brought before it. ${ }^{20}$ For the taxpayer, the use of these rigid tests made it more difficult, insofar as shifting tax incidence was concerned, to effect a gift of a family business interest through a partnership than through a corporation or a trust.

In the Culbertson case the Supreme Court set forth its own interpretation of the Tower decision, providing a new approach to the partnership problem. The Tax Court had ruled that the entire income from the alleged partnership be-

${ }^{r 6}$ Int. Rev. Code $\S$ I8I, 26 U.S.C.A. § I8I (I948).

${ }_{17}$ Lucas v. Earl did not involve a partnership, but rather an agreement to split income. The general principle of that case required elaboration for application to the partnerships of these later years.

${ }^{28} 327$ U.S. 280 (I946). Lusthaus v. Comm'r, 327 U.S. 293 (I946), was a companion case.

${ }^{29} 327$ U.S. 280,290 ( $\left.{ }^{9} 946\right)$.

${ }^{20}$ Illustrative cases are Edgar Minton, 7 T.C.M. 638 (I948); Anthony C. Stralla, 9 T.C. 8or (1047); Gustave C. Gennert, 9 T.C. Iog9 (1947); Wade E. Moore, 7 T.C. r250 (r946). 
tween Culbertson and his sons was taxable to Culbertson, reasoning that since the sons had contributed neither original capital nor vital services, the partnership failed to meet the tests set up by the Tower case. ${ }^{21}$ The Court of Appeals for the Fifth Circuit reversed this decision, ruling that since the partnership was entered into without thought of tax avoidance, and since the expectation and purpose of the agreement was for the sons to contribute their time and services in the future, the Tower tests had been met. ${ }^{22}$

In reversing the Court of Appeals decision and remanding the case to the Tax Court, the Supreme Court carefully corrected the "misinterpretation" of the Tower decision. The use of the tests of original capital, vital services, and control and management of the business indicated "at best, an error in emphasis, ${ }^{\prime 2}{ }^{23}$ said Chief Justice Vinson. The ultimate question in the partnership cases is not whether the importance of services or capital contributed by a partner is sufficient to meet some objective standard, but whether "considering all the facts ... the parties in good faith and acting with a business purpose intended to join together in the present conduct of the enterprise." ${ }^{34}$ This intent is to be found by looking at all of the evidence that throws light on the state of mind of the parties to the agreement.

This search for "intent" might be administered in many ways. Indeed, cases in the wake of the Culbertson decision indicate that it has meant all things to all judges. One court stressed the absence of a tax avoidance motive as a key factor in showing an intent to form a partnership. ${ }^{25}$ Another held that the fact that the alleged partner did not have control over the income from the business was inconsistent with a valid intent to form a partnership. ${ }^{26}$ One case in which the Tax Court had held for the Commissioner was remanded without opinion, directing the Tax Court to apply the principles of the Culbertson decision, ${ }^{27}$ although that court had considered all the evidence and had based its decision on lack of intent. A similar Tax Court decision was affirmed by another circuit court, ${ }^{28}$ even though there had been a contribution of some original capital. Within the Tax Court itself there is considerable disagreement as to what the

22 6 T.C.M. 692 (I947).

${ }^{22}$ I68 F. 2d 979 (C.A. 5th, I948). On appeal to the Supreme Court, Chief Justice Vinson, in reversing, pointed out that the vagaries of human conduct prevent such reliance by the government on the future conduct of the partners. See 47 Mich. L. Rev. 595 (I949), noting the Court of Appeals decision.

${ }^{23} 337$ U.S. 733, 74I (1949).

24 Ibid., at 742 .

25 Greenberger v. Comm'r, r77 F. 2d 990 (C.A. 7th, 1949). The court declared that the Culbertson case placed some limitation upon the Tower case, but that the extent of such limitation need not be determined for this case.

${ }^{26}$ Grayson v. Deal, 85 F. Supp. 43 I (Ala., I949). The district judge set aside the jury verdict and ordered a new trial.

27 Harris v. Comm'r, 175 F. 2d 444 (C.A. 9th, 1949).

${ }_{28}^{8}$ Morrison v. Comm'r, 777 F. 2d 35 I (C.A. 2d, r949). 
Culbertson case means. In one case the partnership was held valid since the donee invested in the partnership the proceeds of the stock of the recently dissolved family corporation. ${ }^{29}$ Six judges, dissenting, claimed that this was not sufficient, particularly since the donee had not shared in the income. The dissenters were among the majority on another case where it was held that in the absence of participation in the affairs of the business, or in managing or controlling the business, the gift of a partnership interest was mere camouflage. ${ }^{30} \mathrm{~A}$ tendency in many of the cases is to resolve factual doubts in favor of the taxpayer although he has the burden of proof when attempting to upset a finding by the Commissioner. ${ }^{3 x}$

An approach that fits into the stream of developments to the Culbertson case is to view the family partnership exactly as a family trust or a gift of stock in a family corporation: if the donor has actually intended to divest himself of control over the partnership interest and the extrinsic facts surrounding the partnership agreement evidence this intent, then in any case the partnership is to be given tax recognition. Such treatment would be sensible in cases where capital is primarily responsible for partnership income, since in these cases a gift of a partnership interest closely resembles a gift of income-producing property. Even though the nature of partnership interests allows the donor some control over the property given, the tax recognition accorded property transfers accomplished by trusts or stock gifts seems to justify shifting tax incidence. Chief Justice Vinson indicated this result, saying, "If the donee of property who then invests it in the family partnership exercises dominion and control over that property-and through that control influences the conduct of the partnership and the disposition of its income--he may well be a true partner. Whether he is free to, and does enjoy the fruits of the partnership is strongly indicative of the reality of his participation in the enterprise." ${ }^{32}$ Such an approach departs from the interpretation of the Tower decision adopted by the lower courts, since the three "tests" excluded any possibility of finding for the taxpayer in cases of this type, regardless of the importance of the capital in the production of income.33 However, in the absence of legislation there may be

29 Edward A. Theurkäuf, r $_{3}$ T.C. 529 (I949).

30 W. F. Harmon, I3 T.C. 373 (I949). In O. H. Delchamps, I3 T.C. 28I (I949), the Tax Court held a partnership valid for tax purposes where the donees had contributed some capital and in addition had put their personal assets at risk so as to strengthen the credit of the business. This type of case has arisen infrequently, but it would seem that even under the Tower interpretation, the Tax Court would have found such a partnership valid, likening the risking of assets to a contribution of original capital. Compare Hartz v. Comm'r, r7o F. 2d 3 I3 (C.C.A. 8th, I948).

3x The Court of Appeals for the Fifth Circuit affirmed a district court finding for the Commissioner in Ginsberg v. Arnold, I76 F. $2 d 879$ (C.A. 5th, r949), basing its decision on the Culbertson case. On rehearing, however, the case was sent back to the district court for application of the principles of the Culbertson case.

${ }^{32}$ Comm'r v. Culbertson, 337 U.S. 733, 747 (r949).

${ }_{33}$ See Tuttle and Wilson, Confusion on Family Partnerships, 9 Ga. Bar J. 353 (I948). 
much uncertainty as to what controls the donor may retain without losing income tax recognition for the gift. Regulations promulgated by the Treasury could concede certain controls to the taxpayer, but those not so conceded could only be resolved by litigation.

This approach has a weakness in partnerships where services are of prime importance to the production of income and where it is clear that the donee of an interest in the partnership has failed to contribute any vital services to the business. It is here that the administration of the Culbertson decision might become difficult. No court could reasonably hold that where the income is wholly attributable to personal services, the donee of a partnership interest who did not perform any services is entitled to share in the income for tax purposes. The doctrine of Lucas v. Earl would prohibit such a holding. But how does the Culbertson case affect a partnership in which the capital is responsible for only ten per cent of the income, and personal services for the rest? If the courts ask only whether the donor of a half-interest in such a partnership actually intended to vest the donee with the ownership thereof, and then hold the donee entitled to half the income for tax purposes, they are allowing a rerouting of 45 per cent of the income, contrary to Lucas v. Earl. In short, both the problems of preventing the rerouting of income from personal services, and of determining whether the donor has actually divested himself of control over the gift may be involved in such a case. Nothing in the Culbertson decision indicates that the courts are to ignore the first problem and base their decisions only on the finding as to whether the donor actually made a complete gift of property to the donee. On the contrary, the failure of the donee to contribute vital services where they are the prime factor in the production of income can well be considered inconsistent with a finding that "the parties in good faith and acting with a business purpose intended to join together in the present conduct of the enterprise." ${ }_{34}$ Other factors, such as the strengthening of credit which is necessary for the partnership to function efficiently, and which provides the framework within which the personal services can earn the income, or the contribution of the donee's supervision or participation in policy decisions, could substitute for a contribution of actual services.

It is apparent that the rerouting of income derived from personal services can be accomplished within a family corporation as well as a family partnership. To the extent that an employee-stockholder accepts as salary less than the value of his services, income from the services is routed to the corporation and ultimately, in part, to the other stockholders. However, because of the corporation tax, and, in the past, the excess profits tax, it is the exceptional situation in which a tax saving can be made through this device, and generally the employee-stockholder takes as salary at least the reasonable value of his services. 35

34 Comm'r v. Culbertson, 337 U.S. 733, 742 (1949).

35 Many small family corporations pay out their entire earnings to employee-stockholders as salaries so as to avoid a showing of any income taxable to the corporation. 
Where a rerouting does occur in the family corporation, it has been upheld on the theory that the recognition in the Code of the corporation as a taxable entity holds the corporation as the earner of the income, and not its employees or stockholders: $3^{6}$ the performer of services is compensated by his salary; the corporation pays a tax on its income; and what is left of the corporation's income goes to the stockholders, if dividends are declared, as earnings on the capital which they have invested. This theory ignores the realities of the situation and does not satisfy the principle of Lucas v. Earl. Tax avoidance through the payment of excessive salaries to employee-stockholders has been successfully attacked by the Commissioner, ${ }^{37}$ and if corporate tax rates are ever lowered so as to make the "small salary" plan attractive, there is no justification in the tax laws for allowing avoidance accomplished through the payment of disproportionately small salaries..$^{8}$

If the Supreme Court frowned on the use of the Tower "tests" primarily because they precluded the Tax Court from recognizing the right to shift tax incidence by giving away income-producing property through a gift of a partnership interest, the Culbertson case does not answer the problem of how this right is to be recognized in the partnership cases without allowing a shifting of income earned through personal services. ${ }^{39}$ In Clare L. Canfield, ${ }^{40}$ the Tax Court attempted to reallocate the division of income among the partners in relation to the services and the capital. $4^{4}$ The circuit court reversed the decision, $4^{2}$ holding that this could not be done where the parties by agreement had decided on a different allocation. This reversal came after the Commissioner had set forth a policy which called for a reallocation procedure in the making of out-of-court settlements. ${ }^{43}$ Reallocation by the Tax Court has not since been attempted, although that court and the circuit court upheld (without any statement of the

${ }^{36}$ See Rossmoore v. Comm'r, 76 F. 2d 520 (C.C.A. 2d, 1935).

37 Long Island Drug Co. v. Comm'r, III F. 2d 593 (C.C.A. 2d, I940), cert. den. 3 II U.S. 680 (1940).

${ }^{38}$ See Alexandre, The Corporate Counterpart of the Family Partnership, 2 Tax L. Rev. 493 (I946), in which it is argued that intra-family gifts of corporate stock should be invalidated for tax purposes where personal services are an income-producing factor. Compare the dissenting opinion in Comm'r v. Montgomery, I44 F. $2 \mathrm{~d}_{3}$ r $_{3}$, 3 I6 (C.C.A. $5^{\text {th, }}$ 1944).

39 One writer suggests that the problem be ignored and that partnerships be recognized according only to the principles laid down by the state in which they are formed: see Fink, The Lusthaus and Tower Cases: Congressional Action Recommended, 20 Fla. L. J. 26r (I946).

${ }^{40} 7$ T.C. 944 (1946).

${ }^{4}$ See Mannheimer and Mook, A Taxwise Evaluation of Family Partnerships, 32 Iowa L. Rev. 436,456 (I947).

$4^{2}$ Canfield v. Comm'r, I68 F. 2 d 907 (C.C.A. 6th, 1948). The decision, however, did not completely close the door to such reallocations. See Haskell, Capital Contributions and Business Purpose in Family Partnerships, 33 Minn. L. Rev. 7I4, 730 n. 44 (r949).

${ }^{43}$ I 947 -I Int. Rev. Cum. Bull. 66-68. 
principles involved) a reallocation by the Commissioner. 44 The Supreme Court expressly leaves the question open in the Culbertson decision, saying, "No question as to the allocation between capital and services is presented in this case, and we intimate no opinion on that subject." 45

The legal criterion established in the Culbertson case is indefinite. In the absence of regulations accepted by the courts resolving this indefiniteness, the Commissioner will lack guidance in determining what deficiencies to press, and the taxpayer in what deficiencies to appeal. Since the finding of intent in any particular case is not necessarily a basis for such a finding in subsequent cases involving even slight changes in fact situations, the Commissioner may be amenable to out-of-court settlements and less inclined to appeal adverse Tax Court rulings. This is particularly true in view of the decreasing number of taxmotivated family partnerships. The split-income provision of the I 948 revenue act has removed the incentive for husband-wife partnerships, which represented the bulk of the family partnership litigation. ${ }^{46}$ In addition, the number of deficiencies assessed by the Commissioner has caused tax consultants to think twice before recommending a family partnership as a means of lowering taxes. The Culbertson decision, then, will primarily affect pending litigation and investigations by the Commissioner. This combination of circumstances may serve to cut down the amount of litigation, with the Commissioner adopting the position that the family partnership is an old problem, and that there are too many other problems which require his attention.

The decision in the Culbertson case will not cause a widespread return to the family partnership as a tax avoidance measure, nor has it shaken the legal principles under which the Tax Court has operated in the past. A non-sham gift of an interest in a partnership in which the capital is the primary income-producing factor will probably be recognized for tax purposes. Where services are of prime importance in the production of income, a reallocation system for dividing income between capital and services, preferably administered by the Commissioner, ${ }^{47}$ is one answer to the problem of how to permit a taxpayer to make a gift of income-producing property through a transfer of a partnership interest and still prevent him from routing to his donee income earned by personal services. If such a procedure is developed, the $C$ ulbertson case is a basis for extending partial recognition to almost all family partnerships. Until such a system is established, the decisions will more be linked to what the lower courts think the Supreme Court has said than to anything actually found in the opinion. An important by-product of the decision, however, may well be a speedy

44 Morrison v. Comm'r, 177 F. 2d $35^{I}$ (C.A. 2d, r949).

${ }^{45} 337$ U.S. 733,748 (I949).

${ }_{4}^{6}$ Int. Rev. Code $\$ 5$ I (b) (I948), 26 U.S.C.A. $\& 5$ I(b) (Supp. x948).

${ }_{47}$ See Eisenstein, Some İconoclastic Reflections on Tax Administration, 58 Harv. L. Rev. 477,526 (I945). 
disentanglement of the backlog of family partnership disputes, a result effected by encouraging settlement of pending disputes and by discouraging appeals and reversals. ${ }^{48}$

\section{SUCCESSION TO TRUSTEESHIP UPON CONSOLIDATION OR MERGER OF CORPORATE FIDUCIARY}

While in most jurisdictions all rights and obligations of consolidating or merging corporations are automatically transferred to the resulting corporation, some states condition succession to trusteeships upon court approval. ${ }^{2}$ This requirement stems from the rule against delegating trusteeships, the emerging corporation being considered a legal entity different from the appointed trustee. ${ }^{2}$ The requirement is said to be justified by the reliance of a settlor on the trustee's personal interest in the beneficiaries, business judgment, and financial responsibility. Although sound when applied to natural trustees, such reasoning seems inappropriate when the trustee is a corporation. ${ }^{3}$ The size and activity of corporate trustees belie the notion that there is anything personal about their administration of trusts. ${ }^{4}$ As for faith in business judgment, limitations imposed by statute and judicial standards of prudence leave little scope

${ }^{4}$ Since the Culbertson case makes the ultimate issue one of intent, necessarily a finding of fact, it could be argued that the decision provides few grounds upon which an appellate court could reverse a Tax Court decision. However, the appellate courts accepted the Tax Court interpretation of the Tower case, and it would seem that only findings of fact were involved prior to the Culbertson case; hence perhaps no improvement can be expected. At least it can be hoped that more respect will be given to Tax Court findings in view of the finality which the Supreme Court indicated should be accorded them.

I Unless, of course, the trust instrument provides otherwise. Generally, consult 3 Bogert, Trusts and Trustees $\S 53 \mathrm{I}$ (rev. ed. I946); Fruchtman, The Effect of Merger or Consolidation on the Succession of Corporate Trustees, 22 Ky. L. J. 378 (I934); Bogert, Some Recent Developments in the Law of Trusts, 23 IIl. L. Rev. 749, 757-65 (I929). Twenty states have statutes explicitly providing for automatic succession to fiduciary relationships by the resulting corporation. 3 Bogert, op. cit. supra at $325 \mathrm{n}$. 15 . The court approval requirement is the result of judicial limitation of consolidation statutes providing in general terms for automatic transfer of rights and obligations. Compare Stevens v. First Nat. Bank, x73 Ga. 332, 160 S.E. 243 (r93I); Hofheimer v. Seaboard Cit. Nat. Bank, $x_{54}$ Va. 392, $x_{53}$ S.E. 656 (r930); Commonwealth-Atlantic Nat. Bank of Boston, petitioner, 249 Mass. 440, I44 N.E. 443 (I924). For an exhaustive tabulation and analysis of state statutes, see Fruchtman, op. cit. supra at 389-99. It is now standard practice to provide in the trust instrument for automatic succession by the resulting corporation in the event of consolidation or merger. 3 Bogert, op. cit. supra at $325 ; x$ Scott on Trusts $\$ 96.7$ (1939).

2 Cases cited note I supra; 3 Bogert, Trusts and Trustees $\S 531$ at 322-25 (rev. ed. r946).

3 See First Nat. Bank of Chattanooga v. Harry E. Chapman Co., x60 Tenn. 72, 22 S.W. 2d 245 (I929); Chicago Title \& Trust Co. v. Zinser, 264 IIl. 3I, 105 N.E. 718 (I914); In re Bergdorf's Will, 206 N.Y. 309, 99 N.E. 7I4 (I912). But see Fruchtman, op. cit. supra note I, at 394-96; Bogert, Some Recent Developments in the Law of Trusts, 23 Ill. L. Rev. 749, 765 (xg29).

4 In I947, 2,976 American companies controlled $\$ 36,162,16 \mathrm{x}, 448$ of personal trust property, the average being about \$I million per company. Stephenson, Trust Business in the United States, I947, 86 Trusts \& Estates 206 ( I948). See Institutionalized Trusteeship, 58 Yale L. J. 924 ( 1949$)$. 